\title{
The effect of hydrazine derivatives of 3-formylchromones on angiogenic basic fibroblast growth factor and fibroblast growth factor receptor-1 in human melanoma cell line WM-115
}

\author{
Andrzej Łazarenkow ${ }^{凶}$, Marta Michalska², Marek Mirowski², Krzysztof Słomiak and \\ Jolanta Nawrot-Modranka'
}

1Department of Bioinorganic Chemistry, Chair of Medicinal Chemistry, Faculty of Pharmacy, Medical University of Łódź, Łódź, Poland; 2 Department of Pharmaceutical Biochemistry and Molecular Diagnostics, Interdepartmental Chair of Laboratory and Molecular Diagnostics, Faculty of Pharmacy, Medical University of Łódź, Łódź, Poland

The hydrazine derivatives of benzopyrones remain an unexplored group of chemical compounds. This preliminary study investigates the influence of $\mathrm{A}-5, \mathrm{CH}-3$ and K-2 derivatives at concentrations of 1, 10, $100 \mathrm{nM}$ and $1 \mu \mathrm{M}$ on selected biochemical factors of a melanoma cell line WM-115, with regard to their potential angiogenic properties. The studied compounds were found to influence cell proliferation, as well as total protein, bFGF and FGFR1 concentration.

Key words: angiogenesis, basic fibroblast growth factor, fibroblast growth factor receptor 1, human melanoma, hydrazone derivatives of benzo- $\gamma$-pyrones

Received: 14 March, 2017; revised: 11 July, 2017; accepted: 14 July, 2017; available on-line: 07 September, 2017

e-mail: andrzej.lazarenkow@umed.lodz.pl

Abbreviations: bFGF, basic fibroblast growth factor; FGFR1, fibroblast growth factor receptor 1; WM-115, human melanoma cell line; BCA, bicinchoninic acid

\section{INTRODUCTION}

The concept that "tumor growth is angiogenesis dependent" was first proposed in 1971 (Folkman, 1990), and states that the growth of a tumor must be preceded by an increase in the number of vessels. Blood vessel development is closely associated with angiogenic factors, which can both, stimulate or inhibit angiogenesis, including an effect on the basic fibroblast growth factor (bFGF, also called FGF2). FGF1, FGF2, and their receptors, FGFR1 and FGFR2 respectively, are the main FGF molecules involved in angiogenesis, resulting in endothelial proliferation, migration and differentiation (Dell'Era et al., 2001; Javerzat et al., 2002; Presta et al., 2005; Khan \& Bicknell, 2016), while the expression of FGFR3 or FGFR4 has never been reported in the endothelial tissue (Presta et al., 2005). Excessive mitogenic signaling through the FGF/FGFR axis may induce carcinogenic effects by promoting cancer progression and increasing the angiogenic potential, which can lead to metastatic tumor phenotypes (Akl MR et al., 2016).

FGF regulates cell migration. The existence of FGF2dependent cell/cell communication between melanoma/ endothelial cells and melanoma/melanoma cells has been found recently (Baljinnyam et al., 2014). The FGFR inhibition led to antitumor effects against melanoma cells in vitro and in vivo (Metzner et al., 2011), and evidence of FGF2 participation in the activity of melanoma cells on surrounding keratinocytes was also reported (Gartside et al., 2009; Kodet et al., 2015). Fortunately, normal melanocytes only produce low levels of the above-mentioned factors, if any (Halaban, 2000). bFGF seems to be one of the major autocrine growth factors associated with tumor progression in melanoma (Berking et al., 2001; Demirkesen et al., 2006).

Some derivatives described in the literature e.g. GSF (Marano et al., 2012), sunitinib, and bevacizumab (Adamcic et al., 2012), exert a similar influence on melanoma cells (including WM-115) and human umbilical vein endothelial (HUVEC) cells or their biologically similar human bone marrow endothelial cells HBMEC-60 (Moehler et al., 2008; Willhauck-Fleckenstein et al., 2010). The mechanisms of action could be also associated with FGF2 (Tran et al., 2016).

One of the well-known hydrazine derivatives is procarbazine, which is used as an anticancer drug in cases like the malignant melanoma, lymphomas, glyomas and brain tumors (Chaar et al., 2006; Armand et al., 2007). However, a significant mutagenic activity of procarbazine has been found (Pletsa et al., 1997), so obtaining of new hydrazine derivatives with low systemic cytotoxicity is highly desirable.

Synthetic analogs of benzopyrones have a very broad spectrum of biological activity, however, hydrazine derivatives of benzopyrones remain a poorly analyzed group of compounds, including their antibacterial (Khan et al., 2010; Nawrot-Modranka et al., 2006) and anticancer properties (Nawrot-Modranka et al., 2006; Lazarenkow et al., 2012). The influence of phosphorohydrazone derivatives of chromone on fibrin polymerization in the presence of bFGF (Michalska et al., 2013) and the influence of 3-formylochromone derivatives on the level of bFGF in the HL-60 cell line (Lazarenkow et al., 2013) have also been reported. Our present study is an investigation on the influence of hydrazine derivatives of 3-formylchromones (A-5, CH-3 and $\mathbf{K}-2$ ) at concentrations of $1,10,100 \mathrm{nM}$ and $1 \mu \mathrm{M}$ on angiogenic bFGF and its receptor FGFR1. Based on the reasons above, and because it is a preliminary study, we decided to use one cultured in vitro cell line in this investigation - human malignant melanoma WM-115.

\section{MATERIALS AND METHODS}

Cell culture. The WM-115 cell line (human melanoma, ATCC Collection) was provided as a monolayer in $75 \mathrm{~cm}^{2}$ Nunclon culture bottles with an adhesive coating (NUNC, Denmark) using Dulbecco's medium with 
$4.5 \mathrm{~g} / \mathrm{L}$ of L-glutamine (DMEM + Glutamax TM-I, Gibco $^{\circledR}$ by Life Technologies ${ }^{\text {TM }}$, Netherlands), supplemented with $10 \%$ FBS and gentamicin at $25 \mu \mathrm{g} / \mathrm{mL}$. The cell line was incubated in a Shell Lab TC 2323 (USA) incubator at $37^{\circ} \mathrm{C}$ in $5 \%$ carbon dioxide and $60 \%$ humidity. After reaching approximately $75-85 \%$ confluence i.e. after three days, the cells were repassaged.

WM-115 exposure to the tested compounds. 80000 cells were transferred to a culture utensil $(5 \mathrm{~cm}$ in diameter) with adhesive layer (NUNC, Denmark) containing $5 \mathrm{~mL}$ of the culture medium described above. After a 24-hour incubation, culture medium exchange was performed using a no-serum base containing only $25 \mu \mathrm{g} /$ $\mathrm{mL}$ gentamicin with one of the tested compounds at a concentration of $1,10,100 \mathrm{nM}$ or $1 \mu \mathrm{M}$. The tested substances were dissolved in 99.9+\% DMSO (Alfa Aesar, Germany) and further diluted with culture medium before being added to the cells. Control samples consisted of DMSO and cell culture only. The final DMSO concentration in the sample was less than $0.02 \%$. Exposure times were 5, 12, 24 and 48 hours.

Preparation of cell lysates of WM-115. After trypsinization, cell suspension was centrifuged in Eppendorf tubes for three minutes at $3500 \mathrm{rpm}$ in an Eppendorf centrifuge (Germany). The cell sediment had been washed three times with PBS (Phosphate buffered saline, $0.1 \mathrm{~mol} / 1, \mathrm{pH} 7.3)$, secured and stored in a freezer at $-70^{\circ} \mathrm{C}$ until further use. For lysis, $700 \mu \mathrm{l}$ of a lysis buffer (10 mM TRIS (Tris(hydroxymethyl)aminomethane, $\mathrm{pH}$ 7.5, SERVA, Germany), $100 \mu \mathrm{M}$ PMSF (Phenylmethylsulfonyl fluoride, Sigma), $300 \mathrm{mM} \mathrm{NaCl}$ (ChemPur, Poland), $2 \mathrm{mM} \mathrm{MgCl}_{2}$ (POCH, Poland) and $10 \mathrm{~mL} / \mathrm{L}$ of Triton X-100 (Northampton, UK)) was added and the mixture was placed in an ice bath for 2.5 hours. The lysates were centrifuged to remove cellular residues and kept frozen at $-70^{\circ} \mathrm{C}$.

Cell proliferation studies. Cell proliferation was investigated using the MTT method. In a 96-well plate, 3000 cells were incubated overnight in $100 \mu \mathrm{L}$ of medium, as described before. Control wells were not seeded with cells. The medium was then replaced by $100 \mu \mathrm{L}$ of a medium with (or without in the case of control) the compounds of interest. Exposure times were 5, 12, 24 and 48 hours. The MTT solution $(10 \mu \mathrm{L}$ of $5 \mathrm{mg} / \mathrm{mL})$ was added two hours before the end of exposure and incubated until the end of the exposure time. Next, the medium was removed and MTT-formazan crystals were dissolved in $100 \mu \mathrm{L}$ of a solubilizer $(700 \mathrm{mM}$ sodium dodecyl sulphate (Sigma), 4.778 M dimethylformamide (Sigma) and $200 \mu \mathrm{M}$ $\mathrm{HCl}$ (concentrated, POCH, Poland)). Each experiment was repeated six times. Readings $(n=1)$ were performed using a Perkin Elmer Victor $\mathrm{V}^{3}$ plate reader (USA) at a wavelength of $562 \mathrm{~nm}$.

Determination of total protein concentration in cell lysates. The BCA method (bicinchoninic acid, Sigma) was used for total protein level determination in 96-microwell plates. Briefly, $25 \mu \mathrm{L}$ of test or control samples and $200 \mu \mathrm{L}$ of BCA (as a mixture of $4 \%$ aqueous solution of $\mathrm{CuSO}_{4}$ with $\mathrm{BCA}$, at a 1:50 ratio) were placed in the wells and incubated for 30 minutes at $37^{\circ} \mathrm{C}$. After incubation, the absorbance was measured using a BIO-TEK El -800 (USA) at a wavelength of $562 \mathrm{~nm}(\mathrm{n}=1)$. Total protein concentration in the cell lysates was calculated by comparing the absorbance results to the standard calibration curve (BSA at 0-1 $\mathrm{mg} / \mathrm{mL}$ in $100 \mu \mathrm{g} / \mathrm{mL}$ steps). Each experiment was repeated twice.
Determination of the level of bFGF in the cell lysates. The assay was performed using the 96-microwell plate RayBio ${ }^{\circledR}$ ELISA kit for human bFGF (RayBiotech, USA) according to the manufacturer's recommendations. As calculated by the manufacturer, the coefficient of variation (CV) for intra-assay measurements is below $10 \%$. Readings ( $n=1$ for single experiment) were performed at $\lambda=562 \mathrm{~nm}$ using a BIO-TEK El $\mathrm{x}_{\mathrm{x}}-800$ plate reader.

Determination of the concentration of FGFR1 in the cell lysates. The test was performed using the 96-microwell plate ELISA kit for human FGFR1 USCNKs (Life Science Inc, PRC) according to the manufacturer's recommendations. Intra-assay precision, as calculated by the manufacturer as $\mathrm{CV}$, is below $10 \%$. Readings ( $\mathrm{n}=1$, single experiment) were performed at $\lambda=450$ $\mathrm{nm}$ using a BIO-TEK El-800 plate reader.

Calculation of the level of bFGF and FGFR1 in total protein content. This was performed as a mathematical recalculation of the obtained results. It's a theoretical investigation, based on the dependence between the cell lysate values of the ELISA tests $\left(\mathrm{C}_{\mathrm{bFGF}}\right.$ or $\mathrm{C}_{\mathrm{FGFR} 1}$ ), the total protein (TP) control results and the protein amount in the lysates from the ELISA control values. The calculations were performed using the equations (Control=100\%):

$$
\begin{aligned}
& \mathrm{C}_{\mathrm{bFGF} \text { in TP }}(\% \text { of Control })=\mathrm{C}_{\mathrm{bFGF}} \times \mathrm{C}_{\mathrm{TP} \text { Control }} \times 100 \% / \\
& \left(\mathrm{C}_{\mathrm{TP}} \times \mathrm{C}_{\mathrm{bFGF} \text { Control }}\right) \\
& \mathrm{C}_{\mathrm{FGFR} 1 \text { in TP }}(\% \text { of Control })=\mathrm{C}_{\mathrm{FGFR} 1} \times \mathrm{C}_{\mathrm{TP} \text { Control }} \times 100 \% / \\
& \left(\mathrm{C}_{\mathrm{TP}} \times \mathrm{C}_{\mathrm{FGFR} 1 \text { Control }}\right)
\end{aligned}
$$

Synthesis of the hydrazone derivatives of 3-formylchromones. Derivatives A-5 (Lazarenkow et al., 2012), CH-3 and K-2 (Nawrot-Modranka et al., 2006), presented in Scheme 1, were all synthesized at the Department of Bioinorganic Chemistry.

Statistical analysis. All figures and needed calculations (i. e. mean, median, \pm S.D., $t$-test, and Shapiro-Wilk test) were made using the Stat-Soft STATISTICA v.13.1 software.

\section{RESULTS AND DISCUSSION}

In the analysis of the obtained results of the WM115 cell proliferation and total protein content (Fig. 1), the dependence between the two (except for $\mathbf{C H}-3$ and K-2 at 24 and 48 hours) was not found. Most likely, the tested compounds exerted a similar influence on some unstudied biochemical parameters in this investigation. Based on the reasons above, the influence of A-5, CH-3 and K-2 on the studied biochemical parameters will be described and discussed separately for their contention in the WM-115 cell lysates and the total protein. The detailed results and calculations are given in the Supplemental Material.

\section{Influence of hydrazone derivatives on WM-115 cell proliferation}

The test was performed using the MTT assay. The results are given as percentage values relative to the control. The derivatives were found to have various effects on the proliferation of WM-115 cells in the concentration range tested: derivative A-5 exerted mainly an anti-proliferative effect, $\mathbf{C H}-3$ mainly encouraged a proliferative activity, and $\mathbf{K}-2$ demonstrated a dual effect. None of the tested derivatives halved 


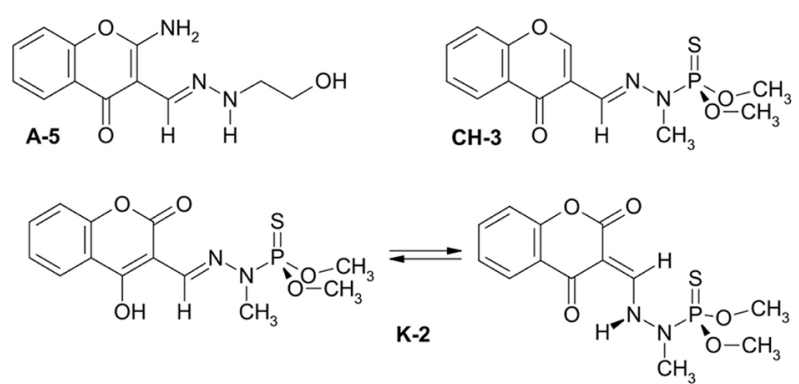

Scheme 1. Structures of the studied compounds.

the cell's inhibition or stimulated cell proliferation over $50 \%$.

The influence of K-2 and $\mathbf{C H}-3$ (in the 24th and 48th hour of experiment, respectively) on the WM-115 cell proliferation exceed $120 \%$, so in the future we plan also use XT'T and/or a BrdU test to exclude obtaining of potentially inappropriate results.

\section{Determination of the total protein concentration in cell lysates}

The absorbance (A) readings recorded during the study were substituted into the formula equation calculated from the obtained standard curve:

$y=0.001215 x+0.146$

as:

\section{$\mathbf{A}=0.001215 \mathbf{c}+0.146$}

The total-protein concentrations (c), in $\mu \mathrm{g} / \mathrm{mL}$, for the cell lysates of the tested compounds $(\mathbf{A}-\mathbf{5}, \mathbf{C H}-\mathbf{3}$ and $\mathbf{K}-2$ ) were calculated; the comparison of the results is given in Fig. 1.

An increase of protein production under the influence of the studied compounds in the WM-115 cells was observed in the first 12 hours of the experiment. A-5 and $\mathbf{K}-2$ were found to have the greatest influence at the 12 th hour at $10 \mathrm{nM}(+93.94 \%$ and $+129.49 \%$ when compared to control, respectively). After 12 hours, the CH-3 and K-2 were found to decrease the protein level, especially at the 24th hour at $100 \mathrm{nM}(-30.3 \%$ and $-48.18 \%$ when compared to control, respectively).

Concentration of bFGF and FGFR1 in WM-115 under the influence of A-5, CH-3 and $\mathrm{K}-2$.

\section{Concentration of bFGF and FGFR1 in cells}

The interpretations of the results obtained in these studies are given in Fig. 2. The border concentrations ( $1 \mathrm{nM}$ and $1 \mu \mathrm{M}$ ) were not as effective as $10 \mathrm{nM}$ (the concentration at which most of the highest values were obtained) and $100 \mathrm{nM}$ (the concentration at which mostly a decreasing influence on the described biochemical parameters was observed).

At $10 \mathrm{nM}$ at the 5 th hour of the experiment, A-5 significantly increased the FGFR1 concentration $(116.13 \%$ above the control value). Besides the 24th hour, A-5 was found to decrease the FGFR1 and bFGF concentrations in the cells; however, at the 5th and 48th hours at 10 nM, A-5's influence on bFGF was low.

CH-3 significantly decreased the FGFR1 concentration (in a range of $9.67-68.03 \%$ when compared to the control). At $100 \mathrm{nM}$ and $1 \mu \mathrm{M}$, a decrease in the bFGF concentration (less than control values in a range of

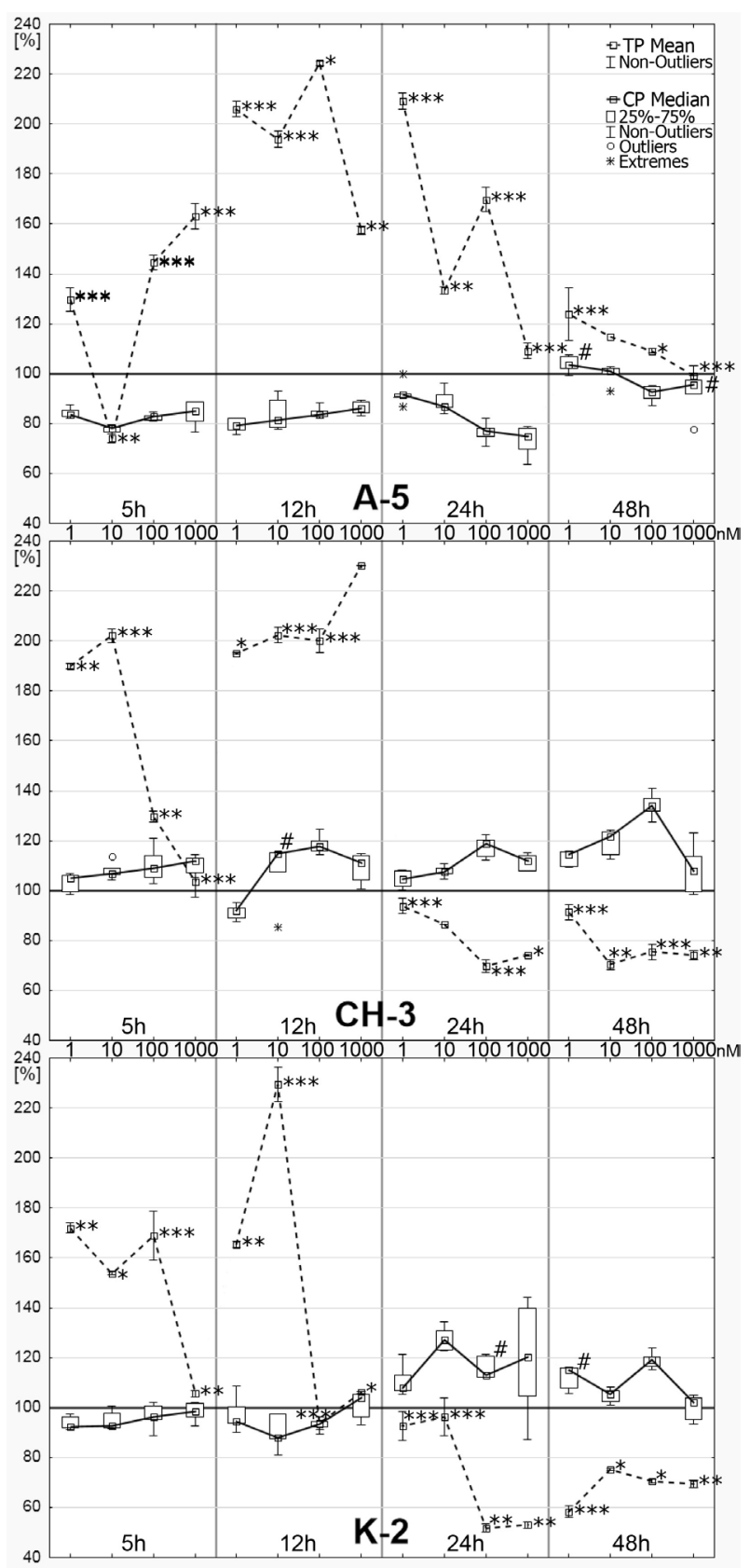

Figure 1. Level of influence (expressed as percent) of the studied compounds on WM-115 cell proliferation and total protein content in the cells.

The cell proliferation study was performed by the MTT test (six experiments). The determination of total protein content was performed twice using the BCA method. Readings were performed at $\lambda=562 \mathrm{~nm}$ for both trials, at 5, 12, 24 and 48 hours of exposing to the studied compounds, which were tested at 1, 10, 100 and 1000 $\mathrm{nM}$ concentrations. The control consisted of non-treated cells only. The results of the MTT test are given as a box-plot of a median rectangle core, which consists of $25-75 \%$ of the non-outlied values. The BCA results are given as a mean of the obtained values. The $t$-test results: ${ }^{* * *} p<0.05,{ }^{* *} p<0.01,{ }^{*} p<0.005$, no asterisk means $p<0.0001 ; \# p<0.05$, Shapiro-Wilk test results, which don't meet the normal distribution criteria. Control=100\%.

24.61-82.03\%) was also observed. After 12 hours, CH-3 influenced both factors differently.

$\mathbf{K}-2$, similarly to $\mathbf{A}-5$, possessed a low selectivity on both angiogenic factors. Except for the 24-hour mark at all concentrations and the 48-hour mark at $1 \mathrm{nM}$, the inhibition of both factors was noted. 


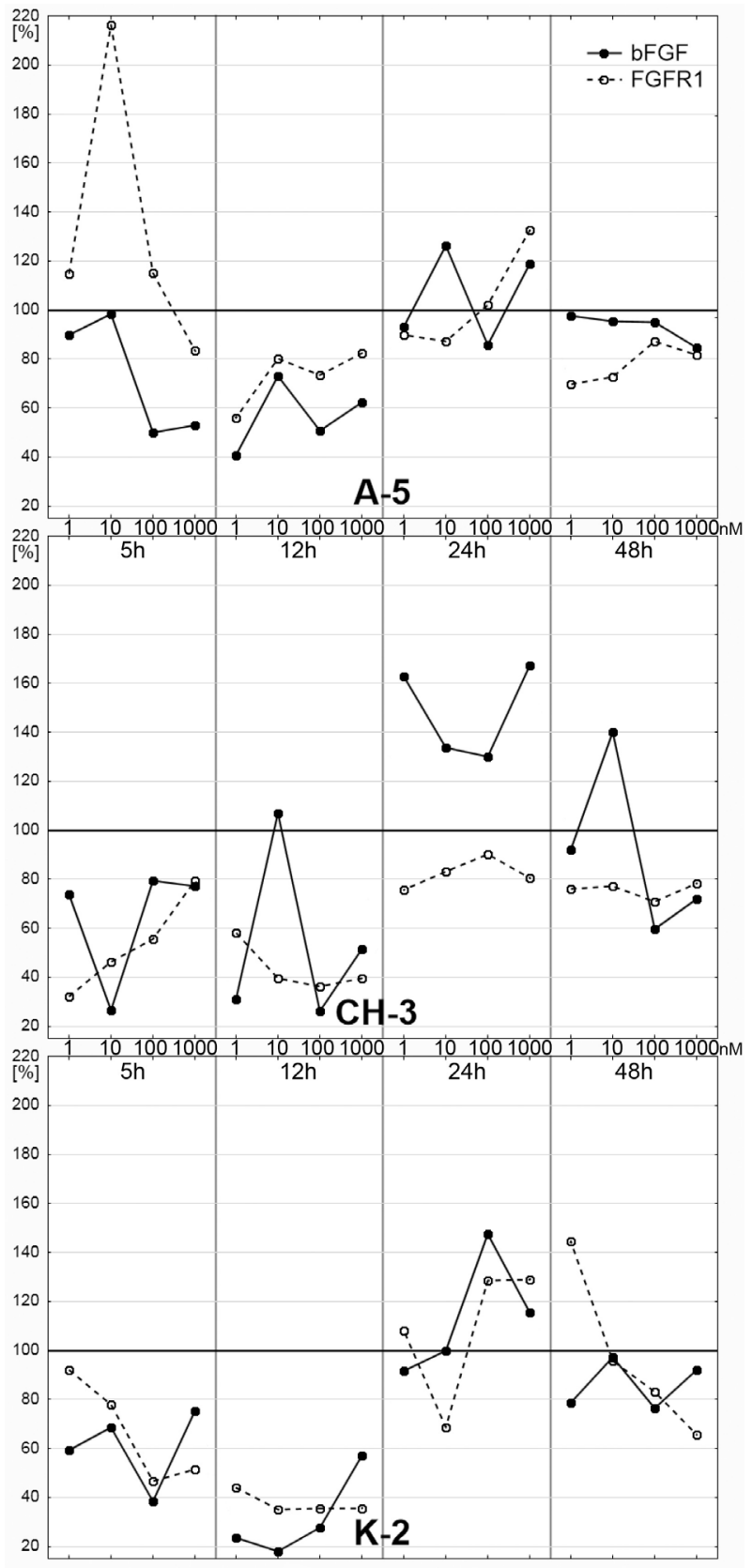

Figure 2. The influence of the studied compounds on the bFGF and FGFR1 concentrations in the WM-115 cell lysates.

This study was performed as single experiment using 96-microwell plate ELISA assays for human bFGF and human FGFR1 according to the manufacturer's recommendations. $C V<10 \%$. Readings were performed at $\lambda=562 \mathrm{~nm}$ for bFGF and $\lambda=450 \mathrm{~nm}$ for FGFR1 at 5, 12, 24 and 48 hours of exposing to the studied compounds, which were tested at 1, 10, 100 and $1000 \mathrm{nM}$ concentrations. The control (100\%) consisted of non-treated cells.

\section{Concentration of bFGF and FGFR1 in total protein content}

There are some similarities between the concentrations of the studied factors in the lysates (Fig. 2) and in relation to the total protein content (Fig. 3). However, the influence of the studied derivatives on bFGF and FGFR1 in the total protein is more significant.

At the 12th and 48th hour of the experiment, A-5 decreased the bFGF and FGFR1 concentrations. The influence on bFGF at the 48th hour was weak, but it

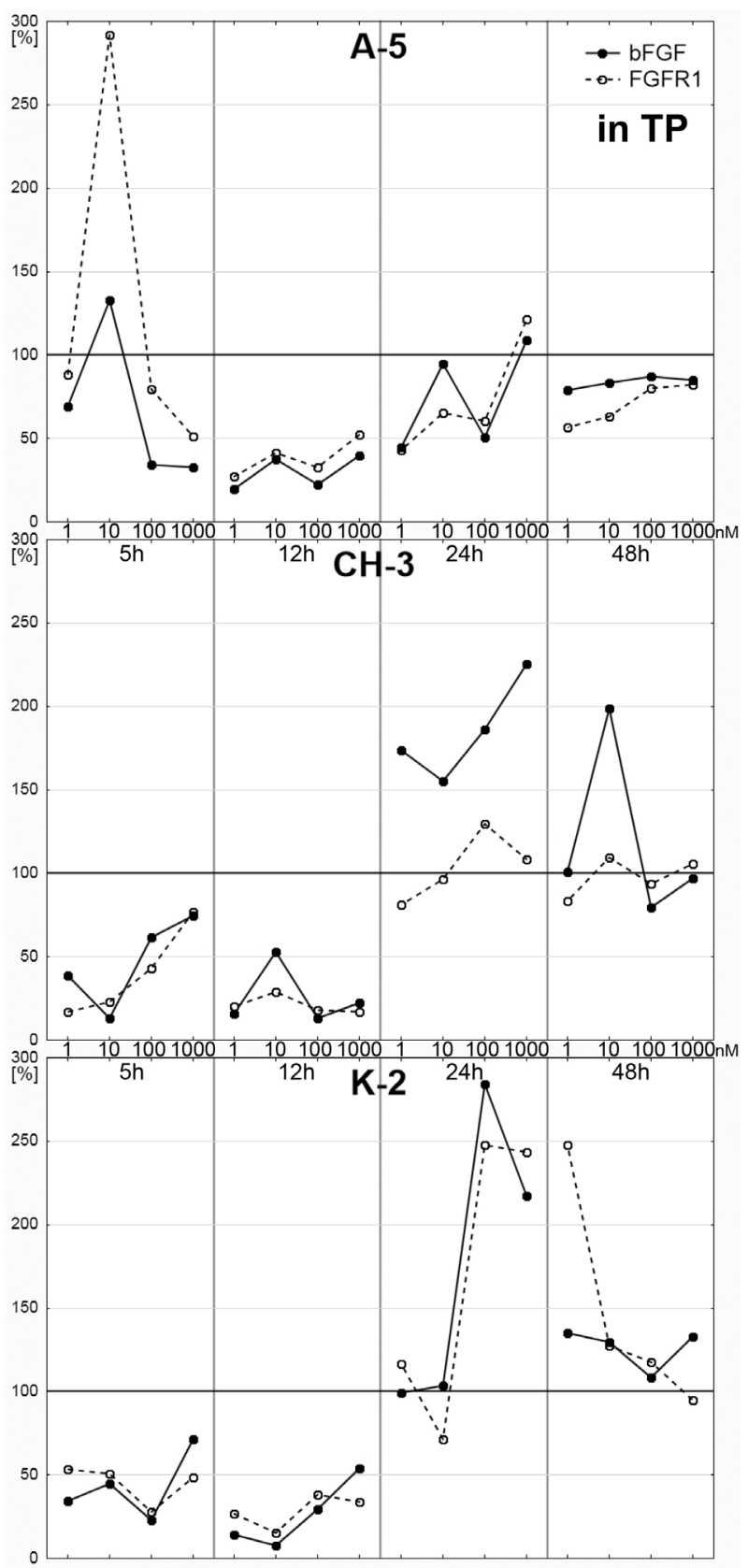

Figure 3 . The influence of the studied compounds on the bFGF and FGFR1 concentrations in WM-115 in relation to the total protein content.

This is a calculation based on the dependence between the cell lysate results of the ELISA tests for bFGF, and the control results of the total protein (TP) with FGF1 and the protein found in the lysates compared to the ELISA control values. Control $=100 \%$. The equations are given in the Materials and Methods section.

was similar at all concentrations tested. At $10 \mathrm{nM}$ at the 5 th hour, the most significant increase in the bFGF and FGFR1 concentrations (132.92 and 291.76\%, respectively) was observed. An increase in both studied parameters was also noted at $1 \mu \mathrm{M}$ at the $24^{\text {th }}$ hour of the experiment (109.03 and $121.65 \%$ for bFGF and FGFR1, respectively). After 5 hours of the experiment, A-5 possessed the lowest selectivity, in comparison to the other tested compounds.

In the first 12 hours of the experiment, $\mathbf{C H}-3$ decreased the concentrations of bFGF and FGFR1. At 
$1 \mu \mathrm{M}$ concentration of $\mathbf{C H}-3$, the most significant increase of bFGF was found after 24 hours of incubation $(225.25 \%)$. After 12 hours, this compound increased the concentrations of both studied factors or influenced them weakly.

The influence of $\mathbf{K}-2$ on bFGF and FGFR1 was similar to that of $\mathbf{C H}-\mathbf{3}$. K-2 had a dual-effect on bFGF; in the first 12 hours, a significant decrease in bFGF was found and in the next 12 hours mainly an increase in the concentration of bFGF was found. This dual effect was also observed on FGFR1. However, after 12 hours, the K-2's influence on this parameter was rather weak and similar to $\mathbf{C H}-3$ 's.

\section{Statistical analysis of results}

The results of the $t$-test of the cell proliferation study showed that it was not necessary to discard $\mathrm{H}_{0}$, because of $p \leq 0.000065$. The Shapiro-Wilk test results for the cell proliferation study met the normal distribution criteria, except: A-5 at $10 \mathrm{nM}$ and $1 \mu \mathrm{M}$ at $48 \mathrm{~h}(p=0.02681$ and 0.04751 , respectively); $\mathbf{C H}-3$ at $10 \mathrm{nM}$ at $12 \mathrm{~h}$ and the control for $\mathbf{C H}-3$ at $48 \mathrm{~h}(p=0.00211$ and 0.01733 , respectively); K-2 at $100 \mathrm{nM}$ at $24 \mathrm{~h}$ and at $1 \mathrm{nM}$ at $48 \mathrm{~h}$ ( $p=0.01053$ and 0.02271 , respectively).

\section{CONCLUSIONS}

When administered in the concentration range of $1 \mathrm{nM}-1 \mu \mathrm{M}$, the $\mathbf{A}-\mathbf{5}, \mathbf{C H}-\mathbf{3}$ and $\mathbf{K}-\mathbf{2}$ derivatives had significantly affected cell proliferation, as well as the concentrations of the total protein, bFGF and FGFR1 in the cell lysates of the WM-115cell line. A-5 was the best in stimulating the production of FGFR1 and inhibition of cell proliferation. In addition, it effectively increased the total protein content in the cell lysates. $\mathbf{C H}-\mathbf{3}$ the most effectively lowered the level of FGFR1 in the cell lysates with total protein content and most actively stimulated cell proliferation. K-2 effectively lowered all of the tested parameters except for the bFGF content in the total protein amount.

Angiogenesis is also affected by other growth factors with their family-specific receptors. The vascular endothelial growth factor family, with its receptors VEGFR1 and VEGFR2, along with FGF1 are commonly observed in solid tumor cases. It is probable that the studied compounds may give similar or greater effects on other proteins, including angiogenic factors and receptors not examined in this preliminary study.

\section{Conflict of interest}

The authors declare no conflict of interest.

\section{Acknowledgements}

A.E. and M.Mich designed and performed the research and analyzed the obtained data; A.E. and J.N.-M. synthesized the studied compounds; A. Ł. and K.S. wrote the manuscript; M.Mir. and J.N.-M. made manuscript corrections.

\section{Financial support}

This research was supported by the Medical University of Łódź, grants No: 503/3-016-02/503-31-001 (A.Ł, J.N.-M. and K.S.), 502-03/3-016-02/502-34-047 (A.E.), 502-03/3-016-02/502-34-063 (J.N-M. and K.S.), 503/3015-02/503-31-001 (M.Mich. and M.Mir.).

\section{REFERENCES}

Adamcic U, Skowronski K, Peters C, Morrison J, Coomber BL (2012) The effect of bevacizumab on human malignant melanoma cells with functional VEGF/VEGFR2 autocrine and intracrine signaling loops. Neoplasia 14: 612-623. http://dx.doi.org/10.1593/neo.11948

Akl MR, Nagpal P, Ayoub NM, Tai B, Prabhu SA, Capac CM, Gliksman M, Goy A, Suh KS (2016) Molecular and clinical significance of fibroblast growth factor 2 (FGF2/bFGF) in malignancies of solid and hematological cancers for personalized therapies. Oncotarget 7: 44735-44762. http://dx.doi.org/10.18632/oncotarget.8203

Armand JP, Ribrag V, Harrousseau JL, Abrey L (2007) Reappraisal of the use of procarbazine in the treatment of lymphomas and brain tumors. Ther Clin Risk Manag 3: 213-224

Baljinnyam E, Umemura M, Chuang C, De Lorenzo MS, Iwatsubo M, Chen S, Goydos JS, Ishikawa Y, Whitelock JM, Iwatsubo K (2014) Epac1 increases migration of endothelial cells and melanoma cells via FGF2-mediated paracrine signaling. Pigment Cell Melanoma Res 27: 611-620. http://dx.doi.org/10.1111/pcmr.12250

Berking C, Takemoto R, Satyamoorthy K, Elenitsas R, Herlyn M (2001) Basic fibroblast growth factor and ultraviolet B transform melanocytes in human skin. Am J Pathol 158: 943-953. http:// dx.doi.org/10.1016/S0002-9440(10)64041-2

Chaar BT, Salem P, Petruska PJ (2006) Procarbazine for non-Hodgkin's lymphoma. Leuk Lymphoma 47: 637-640. http://dx.doi. org/10.1080/10428190600591517

Dell'Era P, Belleri M, Stabile H, Massardi ML, Ribatti D, Presta M (2001) Paracrine and autocrine effects of fibroblast growth factor-4 in endothelial cells. Oncogene 20: 2655-2663. http://dx.doi. org/10.1038/sj.onc. 1204368

Demirkesen C, Büyükpinarbaşili N, Ramazanoğlu R, Oğuz O, Mandel NM, Kaner G (2006) The correlation of angiogenesis with metastasis in primary cutaneous melanoma: a comparative analysis of microvessel density, expression of vascular endothelial growth factor and basic fibroblastic growth factor. Pathology 38: 132-137. http:// dx.doi.org/10.1080/00313020600557565

Folkman J (1990) What is the evidence that tumors are angiogenesis dependent? I Natl Cancer Inst 82: 4-6

Gartside MG, Chen H, Ibrahimi OA, Byron SA, Curtis AV, Wellens CL, Bengston A, Yudt LM, Eliseenkova AV, Ma J, Curtin JA, Hyder P, Harper UL, Riedesel E, Mann GJ, Trent JM, Bastian BC, Meltzer PS, Mohammadi M, Pollock PM (2009) Loss-of-function fibroblast growth factor receptor-2 mutations in melanoma. Mol Cancer Res 7: 41-54. http://dx.doi.org/10.1158/1541-7786.MCR-080021

Halaban R (2000) The regulation of normal melanocyte proliferation. Pigment Cell Res 13: 4-14

Javerzat S, Auguste P, Bikfalvi A (2002) The role of fibroblast growth factors in vascular development. Trends Mol Med 8: 483-489. http:// dx.doi.org/10.1016/S1471-4914(02)02394-8

Khan KA \& Bicknell R (2016) Anti-angiogenic alternatives to VEGF blockade. Clin Exp Metastasis 33: 197-210. http://dx.doi. org/10.1007/s10585-015-9769-3

Khan KM, Ambreen N, Mughal UR, Jalil S, Perveen S, Choudhary MI (2010) 3-Formylchromones: potential antiinflammatory agents. Eur J Med Chem 45: 4058-4064. http://dx.doi.org/10.1016/j.ejmech.2010.05.065

Kodet O, Lacina L, Krejčí E, Dvořánková B, Grim M, Štork J, Kodetová D, Vlček Č, Sáchová J, Kolář M, Strnad H, Smetana K (2015) Melanoma cells influence the differentiation pattern of human epidermal keratinocytes. Mol Cancer 14: 1. http://dx.doi. org/10.1186/1476-4598-14-1

Łazarenkow A, Nawrot-Modranka J, Brzezińska E, Krajewska U, Różalski M (2012) Synthesis, preliminary cytotoxicity evaluation of new 3-formylchromone hydrazones and phosphorohydrazone derivative of coumarin and chromone. Med Chem Res 21: 1861-1868. http://dx.doi.org/10.1007/s00044-011-9703-4

Łazarenkow A, Michalska M, Goraca A, Mirowski M, Nawrot-Modranka J, Piechota-Polanczyk A (2013) The influence of chromone based hydrazones on lipid peroxidation and bFGF concentration in the HL-60 cell line. Acta Biochim Pol 60: 259-262

Marano G, Gronewold C, Frank M, Merling A, Kliem C, Sauer S, Wiessler M, Frei E, Schwartz-Albiez R (2012) An easily accessible sulfated saccharide mimetic inhibits in vitro human tumor cell adhesion and angiogenesis of vascular endothelial cells. Beilstein J Org Chem 8: 787-803. http://dx.doi.org /10.3762/bjoc.8.89

Metzner T, Bedeir A, Held G, Peter-Vörösmarty B, Ghassemi S, Heinzle C, Spiegl-Kreinecker S, Marian B, Holzmann K, Grasl-Kraupp B, Pirker C, Micksche M, Berger W, Heffeter P, Grusch M (2011) Fibroblast growth factor receptors as therapeutic targets in human melanoma: synergism with BRAF inhibition. I Invest Dermatol 131: 2087-2095. http://dx.doi.org/10.1038/jid.2011.177

Michalska M, Mirowski M, Kaplińska K, Kusztal D, Łazarenkow A, Nawrot-Modranka J (2013) Effect of phosphorohydrazone derivatives of chromone on fibrin polymerization in the presence of bFGF. Indian J Biochem Biophys 50: 227-232 
Moehler TM, Sauer S, Witzel M, Andrulis M, Garcia-Vallejo JJ, Grobholz R, Willhauck-Fleckenstein M, Greiner A, Goldschmidt H, Schwartz-Albiez R (2008) Involvement of alpha 1-2-fucosyltransferase I (FUT1) and surface-expressed Lewis(y) (CD174) in first endothelial cell-cell contacts during angiogenesis. J Cell Physiol 215: 27-36. http://dx.doi.org /10.1002/jcp.21285

Nawrot-Modranka J, Nawrot E, Graczyk J (2006) In vivo antitumor, in vitro antibacterial activity and alkylating properties of phosphorohydrazine derivatives of coumarin and chromone. Eur J Med Chem 41: 1301-1309. http://dx.doi.org/10.1016/j.ejmech.2006.06.004

Pletsa V, Valavanis C, van Delft JH, Steenwinkel MJ, Kyrtopoulos SA (1997) DNA damage and mutagenesis induced by procarbazine in $\lambda$ lacZ transgenic mice: evidence that bone marrow mutations do not arise primarily through miscoding by $O^{6}$-methylguanine. Carcinogenesis 18: 2191-2196
Presta M, Dell'Era P, Mitola S, Moroni E, Ronca R, Rusnati M (2005) Fibroblast growth factor/fibroblast growth factor receptor system in angiogenesis. Cytokine Growth Factor Rev 16: 159-178. http://dx.doi. org/10.1016/j.cytogfr.2005.01.004

Tran TA, Leong HS, Pavia-Jimenez A, Fedyshyn S, Yang J, Kucejova B, Sivanand S, Spence P, Xie XJ, Peña-Llopis S, Power N, Brugarolas J (2016) Fibroblast growth factor receptor-dependent and -independent paracrine signaling by sunitinib-resistant renal cell carcinoma. Mol Cell Biol 36: 1836-1855. http://dx.doi.org /10.1128/ MCB.00189-16

Willhauck-Fleckenstein M, Moehler TM, Merling A, Pusunc S, Goldschmidt H, Schwartz-Albiez R (2010) Basement membrane complexes with biological activity. Angiogenesis 13: 25-42. http://dx.doi. org /10.1007/s10456-010-9162-4 